\title{
MODERN CHALLENGES FACING THE VALUATION PROFESSION AND ALLIED UNIVERSITY EDUCATION IN POLAND
}

\author{
Sabina Źróbek, Prof. \\ Faculty of Geodesy and Land Management \\ University of Warmia and Mazury in Olsztyn \\ e-mail: zrobek@uwm.edu.pl \\ Chris Grzesik, M.Sc. \\ The European Group of Valuers' Associations \\ e-mail: chrisg@polishproperties.com.pl
}

\begin{abstract}
The paper indentifies and synthesizes the observed changes in the role of the property valuer on the property market. The authors of this paper provide a perspective on the changes in the educational programs for valuers. The main challenge for valuation professionals lies in developing a deeper understanding of market globalization and better analytical skills, with a view to assessing accurate values. The educational system at the university level should encompass programmes which will prepare valuers for providing proper advice affecting important investment decisions of real estate market participants. They stress the role of international and national organizations in re-shaping the profile of the valuer. The current critical attitude towards the valuation profession has forced the European body representing valuers, namely The European Group of Valuers' Associations (TEGoVA) to speed up the harmonisation of the valuation practice in order to forestall more rigorous control by the EU. In response to this, all the major internationally recognised standard setting bodies, such as the above-mentioned TEGoVA and The Royal Institution of Chartered Surveyors (RICS), are considering the need to add "risk analysis" to valuation reports. Such development should significantly affect future valuation educational and training programmes which will need to present a more holistic approach to real estate as an asset class.
\end{abstract}

Keywords: real estate, education of property valuers, challenge for valuation professionals, TEGoVA, valuation standards.

JEL Classification: R30,A23, A29.

Citation: Źróbek S., Grzesik C., (2013), “Modern challenges facing the valuation profession and allied university education in Poland", Real Estate Management and Valuation, vol. 21, no 1, pp. 14-18.

DOI: $10.2478 /$ remav-2013-0002.

\section{Introduction}

Education in the field of real estate in Poland, including valuation, has evolved in line with the country's economic progress. A fundamental change occurred after 1990, following the introduction of a market economy and a properly functioning real estate market. This resulted in a change in the way property was valued and the demise of the officially set pricing of properties owned by the State Treasury and local authorities. Such changes required a revolution in the education of property valuers.

Furthermore, the globalisation of the real estate market and the widening of tasks imposed on valuers have led to new demands on institutions responsible for educating these specialists (WAGNER 
2001). In Poland, such teaching was originally undertaken by university-run postgraduate courses or specialized master's degree programs.

However, in the recent years the nature of the real estate market has undergone fundamental changes along with the growth in the number of both local and international institutional real estate investors (ŹRÓBEK and ŹRÓBEK 2006).

In addition, when considering the challenges facing valuers and their future educational needs one cannot ignore the growing appetite of the European Union for regulating the processes of property valuation and the profession itself. The political influence of the EU is growing particularly in the Euro zone and this will have a direct effect on the real estate market and valuation. Until recently, the work of property valuers was, to a large extent, free of EU interference. However, this has changed with the global financial crisis because valuations have become the subject of growing criticism and interest. Some commentators regard valuation failure as the basic cause of the financial crisis and consider EU regulatory control to be the inevitable result.

During a European Valuers' Conference held in Rome towards the end of 2012, representatives of 37 valuers' associations from 20 countries in Europe as well as the USA (Appraisal Institute) discussed the challenges facing the profession in a crisis-torn European Union (TEGoVA).

The main challenge for valuation professionals lies in developing a deeper understanding of the market and better analytical skills with a view to assessing accurate values.

\section{Observed and desired changes in the role of the valuer}

At first, the modern valuation profession in Poland developed largely thanks to the work of the State Treasury and local authorities. In particular, valuers were asked to assess publicly owned properties for a variety of purposes, though mainly for property disposal or privatisation. However, such instructions are diminishing with programmes of selling publicly owned assets to sitting tenants or leaseholders now coming to an end. Today, valuers have to look further afield and offer a wider selection of services, including real estate consultancy and investment advice in the capital market.

In 1998, the Statute for Real Estate Management of 29 August 1997 came into effect. This date marked a revolutionary change in professional services relating to a large part of the real estate market in Poland. Education and teaching also evolved at this time, from knowledge passed down by professionals to formalised structured training and finally, to the ever-improving academic teaching at higher educational establishments. Professional disciplines and the educational process are moving from "teaching" and "processing numbers" to an approach which combines different teaching and training methods. The educational system should encompass programmes which will prepare valuers for providing proper advice affecting important investment decisions of real estate market participants. Real Estate education should be characterised by two approaches, which depend on how real estate is perceived- whether as a capital investment or as a fixed asset (land and buildings).

The events in Poland over the last 20 years have been influenced by economic growth as well as development in the theory and practice of valuation. In light of this, one can assume that there will be a convergence of the theory of property valuation and its application in the near future, following the example set by "western countries". Much credit for such a state of affairs should go to academics at many universities, representing different fields of knowledge.

"This "brave new world" of real estate valuation provides considerable promise of finally treating real estate not as the poor orphan stepchild relative to other economic goods and financial assets, but as a full-fledged member of the club. That is not to say that all is rosy with the future of valuation from a professional practice standpoint or with our ability in general to do a significantly better job of making value estimates" (VANDELL 2007).

The uncertainty of the result of a valuer's work is partly due to the fact that real estate is endowed with a diversity of physical, legal and economic characteristics denoting risk which is specific to this market sector in contrast to products in other sectors. Unfortunately, many valuers are slow to embrace and apply new developments in valuation theory and the technology of gathering and processing data, as well as the correct interpretation of the obtained results.

The complexity of and ever closer connection between the capital and real estate markets, changes in legal regulations, and technological change require the knowledge gained during day courses and postgraduate studies to be expanded and updated.

The nature of the real estate market in Poland during the 1990s and the subsequent changes influencing the need to modify the profile of the valuer may be summarised as follows: 


$\begin{array}{lll}\text { Demand } & \rightarrow & \text { Supply } \\ \text { Investment } & \rightarrow & \text { Cost Control } \\ \text { On off advertising } & \rightarrow & \text { Marketing } \\ \text { Short term thinking } & \rightarrow & \text { Longer term thinking } \\ \text { Valuation } & \rightarrow & \text { Valuation and Advice } \\ \text { Individuals working alone } & \rightarrow & \text { Team work }\end{array}$

When addressing these tendencies, the range of professional skills required of valuers may be grouped as follows:

- Technical skills - measurement, calculations, data processing, technical reporting.

- Organisational skills - participation in decision-making processes, cross sectional studies, management.

- Analytical skills - analysis and choice of options/variables, setting parameters and their interpretation.

- Leadership skills - management of people and teams of specialists, management of information flow.

\section{The role of international and national organisations in re-shaping the profile of the valuer}

The current critical attitude towards the valuation profession has forced the European body representing valuers, namely The European Group of Valuers' Associations (TEGoVA), to speed up the harmonisation of the valuation practice in order to forestall more rigorous control by the EU. To this end, in 2012, TEGoVA issued a new edition of European Valuation Standards (EVS 2012) which offer guidance on EU law affecting the valuation practice including, for example, the recently passed Alternative Investment Fund Managers Directive.

Also, the European Parliament is currently debating drafting a new Mortgage Credit Directive in which International Valuation Standards are proposed as the basis for the valuation of residential property (there are voices in favour of expanding the legislation to also cover commercial property) for bank loan purposes.

The growing influence of the EU in matters concerning property valuation is also evident in the area of financial reporting. In accordance with EU regulation, from January 1, 2013 all EU countries must adopt the guidelines set out in the International Financial Reporting Standards - IFRS 13, issued by the International Financial Accounting Standards Board. Notwithstanding the fact that IFRS concern the assessment of "fair value" and not "market value", under International Valuation Standards these two categories of value have hitherto been largely assumed to be the same. It is of particular interest that IFRS 13 not only defines fair value but also, for the first time, interprets it as being based on "the highest and best use of the property". In Poland, this is a significant development in the sense that so far, there has been no consensus within the valuation profession as to the interpretation of the definition of "market value". Thus, many valuers disagree with the proposition that market (or fair value) represent the highest and best use of the property. Yet, in the meantime, the disputable matter has been resolved from above via EU law.

Also on a global level, the valuation profession cannot ignore the growing criticism of the use of market value and a "mark to market" approach to valuation. It seems that, at least for property financing purposes, valuers are not being asked entirely the right question. Currently, they have to assess a property's market value. The problem is that market value simply offers a snapshot of the market at a fixed point in time. An assessment of market value does not answer the question about the sustainability of value in the future.

In connection to this, all the major internationally recognised standard setting bodies, such as TEGoVA and RICS, are considering the need to add "risk analysis" to valuation reports. Such development should significantly affect future valuation educational and training programmes which will need to present a more holistic approach to real estate as an asset class.

It is worth noting here that in response to pressure from the Polish banks and with government backing, the Polish Federation of Valuers' Associations (PFVA) has developed a valuation standard (KSWS3) regulating all valuations for loan security purposes. Under the new standard, valuers, in expressing their opinion on market value, must also undertake a risk analysis of the property being valued. 
The "Europeanisation" of Polish valuers began a few years ago when the Polish Federation of Valuers' Associations (PFVA) implemented TEGoVA's Recognised European Valuer (REV) scheme. At a pan European level, cross border investors have been expressing concerns about the difficulty in identifying reliable valuers with up to date knowledge and appropriate experience. TEGoVA's REV scheme addresses these concerns by affording recognition to appropriately qualified and experienced valuers able to prove an ongoing involvement in property valuation work, participation in a programme of lifelong learning and adherence to a code of professional ethics.

In Poland, a REV certificate may be obtained by all qualified practising valuers without further examination, an acknowledgement of the fact that the Polish licensing system fully meets the minimum educational and training requirements considered acceptable at a European level. Indeed, such requirements are exceeded in Poland.

It should be noted that a REV certificate does not represent a new qualification but rather the acknowledgement that existing qualifications held by the valuer meet several minimum criteria considered essential for a valuer practising in the European property market. Thus, the existing qualifications and experience of a Polish qualified valuer holding a REV certificate may be compared favourably with the qualifications and experience of a Recognised European Valuer in another country (GRZESIK 2012).

\section{Conclusions}

The examples presented above concerning the functioning of today's real estate market point to the growing influence of the European Union on the practice of real estate valuation and over time, to a lessening significance of the Statute of Real Estate Management of 21 August 1997 in Poland. This will also impinge on educational programmes for valuers. More time will need to be devoted to European law and the real estate valuer will need to be educated and trained as a "European". The gaining of an REV certificate is a step in this direction. The valuer will also need to become better acquainted with the global / cross border commercial market which is becoming ever more significant in Poland.

The diversity of applications of valuation reports point to the fact that it is no longer sufficient for valuers to simply report market value. In today's uncertain times, clients require a more detailed analysis of past, present and future market trends, as well as a risk analysis of the property valued.

As aptly put by Roulac "Effective property involvement employs multiple perspectives and skill sets to address the crucial questions for effective property involvements, and applies the capacity to reframe problems, select appropriate methodologies and tools, gather the requisite information, and be self-educating to learn what one needs to know to address the problems one encounters" (ROULAC 2002).

The role of academics will also gradually change. Universities will, to a greater degree, become suppliers of an up-to-date pool of knowledge as well as transparent and clear teaching programmes, offering pointers and strategies to motivate students, whilst the latter will organise their own methods of study. Assistance in the development and updating of knowledge will be facilitated by constantly improving information technology, including geographic information systems - GIS.

The above reflections point to the need for dialog between valuation practitioners and academics of real estate and other disciplines (e.g., finance, sociology, information technology), whose knowledge should be combined when drafting plans for the education of specialists who will provide a wide range of services, not limited to valuation, in the real estate market.

\section{Bibliography}

EUROPEAN VALUATION STANDARDS, 2012, TEGoVA.

GRZESIK K., 2012, Recognised European Valuer- udana europejska certyfikacja rzm., Nieruchomość 2 (82).

GRZESIK K., 2013, Arrivederci Roma, TEGoVA REV Journal.

INTERNATIONAL FINANCIAL REPORTING STANDARDS, 2013, IFRSB.

ROULAC S.E., 2002, Requisite Knowledge for Effective Property Investment In the Global Context, "Real Estate Education Throught the World: Past, Present and Future", ed. K-W. Schulte, Boston, Kluwer ACADEMIC PUBLISHERS, 1 (3-24).

ŹRÓBEK S., ŹRÓBEK R., 2006, Wybrane aspekty rozwoju nieruchomości w kontekście instytucjonalnego rynku, "Studia i Materiaty Towarzystwa Naukowego Nieruchomości", vol. 1-4 issue 1.

KERRY D. VANDELL, 2007, Expanding the academic discipline of real estate valuation: A historical perspective with implications for the future, Journal of Property Investment and Finance, vol. 25, no: 5 pp.427-443. 
TEGoVA REV Journal January 2103 issue no. 2.

VANDELL K.D., 2007, Expanding the academic discipline of real estate valuation, Journal of Property Investment and Finance, vol. 25, no 5.

WAGNER C., 2011, The Appraiser's Role in Today's Real Estate Transaction, www.wagnerappraisal.com. 